medRxiv preprint doi: https://doi.org/10.1101/2021.01.28.21250664; this version posted January $29,2021$. The copyright holder for this preprint (which was not certified by peer review) is the author/funder, who has granted medRxiv a license to display the preprint in

All rights reserved. No reuse allowed without permission.

\title{
Risk of SARS-CoV-2 exposure among hospital healthcare workers in relation to patient contact and type of care
}

Susanna Klevebro ${ }^{1,2}$, Fuad Bahram³ ${ }^{3}$ K. Miriam Elfström ${ }^{4}$, Ulrika Hellberg',2, Sophia Hober ${ }^{5}$, Simon Kebede Merid ${ }^{1}$, Inger Kul1 ${ }^{1,2}$, Peter Nilsson ${ }^{5}$, Per Tornvall ${ }^{1}$, Gang Wang ${ }^{1,6}$, Kalle Conneryd Lundgren, ${ }^{4}$ Sari Ponzer ${ }^{1}$, Joakim Dillner ${ }^{4 *}$, Erik Melén ${ }^{1,2 *}$

* Shared last author

${ }^{1}$ Department of Clinical Science and Education, Södersjukhuset, Karolinska Institutet, Stockholm, Sweden

2 Sachs' Children and Youth Hospital, Södersjukhuset, Stockholm, Sweden

${ }^{3}$ Clinical Reseach Center, Södersjukhuset, Stockholm, Sweden

${ }^{4}$ Karolinska University Hospital, Stockholm, Sweden

${ }^{5}$ Department of Protein Science, KTH Royal Institute of Technology, SciLifeLab, Stockholm, Sweden

${ }^{6}$ Department of Integrated Traditional Chinese and Western Medicine, West China Hospital, Sichuan University, Sichuan, China

Corresponding author:

Professor Erik Melén

Department of Clinical Science and Education, Södersjukhuset, Karolinska Institutet

Sjukhusbacken 10

11883 Stockholm, Sweden

Email: erik.melen@ki.se 
medRxiv preprint doi: https://doi.org/10.1101/2021.01.28.21250664; this version posted January $29,2021$. The copyright holder for this preprint (which was not certified by peer review) is the author/funder, who has granted medRxiv a license to display the preprint in

All rights reserved. No reuse allowed without permission.

\section{Abstract}

Aim: We aimed to assess the risk for severe acute respiratory syndrome coronavirus-2

(SARS-CoV-2) infection in a large cohort of healthcare workers (HCWs).

Methods: From May 11 until June 11, 2020, 3,981 HCWs at a large Swedish Emergency Care hospital provided serum samples and questionnaire data. Exposure was measured by assaying IgG antibodies to SARS-CoV-2.

Results: The total seroprevalence was $17.7 \%$ and increased during the study period. Among the seropositive HCWs, $10.5 \%$ had been entirely asymptomatic. Participants who worked with COVID-19 patients had higher odds for seropositivity: ORadj 1.96 (95\% CI $1.59-2.42$ ). HCWs from three of the departments managing COVID-19 patients had significantly higher seroprevalences, whereas the prevalence among $\mathrm{HCW}$ s from the Intensive Care Unit (also managing COVID-19 patients) was significantly lower.

Conclusion: HCWs in contact with SARS-CoV-2 infected patients had a variable, but on average higher, likelihood for SARS-CoV-2 infections.

Key words: antibodies; COVID-19; healthcare workers; health personnel; SARS-CoV-2; seroepidemiologic studies; seroprevalence

Word count: 1218 
medRxiv preprint doi: https://doi.org/10.1101/2021.01.28.21250664; this version posted January $29,2021$. The copyright holder for this preprint (which was not certified by peer review) is the author/funder, who has granted medRxiv a license to display the preprint in All rights reserved. No reuse allowed without permission.

\section{$\underline{\text { Background }}$}

In February 27, the first confirmed case of SARS-CoV-2 infection in Stockholm, Sweden was diagnosed. ${ }^{1}$ The number of patients in need of hospital care due to COVID-19 in the Stockholm region escalated in March and the beginning of April and started to decline in May. ${ }^{2}$ Healthcare workers (HCWs) with direct patient contact are more exposed to the virus and thereby have a higher risk of contracting SARS-CoV-2 compared to the general population. ${ }^{3-5}$ Presence of SARS-CoV-2 IgG antibodies indicates a previous SARS-CoV-2 infection. A global review of previous studies published up to August 2020 found an overall seroprevalence of SARS-CoV-2 antibodies among HCWs to be $8.7 \%(95 \% \mathrm{CI}: 6.7-10.9 \%){ }^{6}$ The aim of this study was to assess the seroprevalence in a large cohort of HCWs at a Swedish emergency care hospital after the first wave of COVID-19 patient admissions.

\section{$\underline{\text { Methods }}$}

Stockholm South General Hospital (Södersjukhuset) has one of the largest Emergency Care Departments in Northern Europe with about 550 in-patient beds. The hospital provides both general and specialized acute as well elective care. From February 27, when the first case was verified in the region, until June 30, 1,384 patients with confirmed SARS-CoV-2 infection had been admitted to the hospital (online supplement). Guidelines recommended the use of face shields, face masks and plastic aprons during direct contact with patients suspected to be infected. Aerosol filtering face masks were recommended during aerosol generating procedures, and in the ICU. HCWs were advised to stay at home if symptomatic and until feeling well for at least two days but were not routinely tested for SARS-CoV-2 during this period.

This cross-sectional study was initiated as a part of a regional study of HCWs conducted in the major emergency care hospitals in Stockholm, and all HCWs were invited to participate. 
medRxiv preprint doi: https://doi.org/10.1101/2021.01.28.21250664; this version posted January $29,2021$. The copyright holder for this preprint (which was not certified by peer review) is the author/funder, who has granted medRxiv a license to display the preprint in

All rights reserved. No reuse allowed without permission.

Stockholm South General Hospital had 4,641 employees in May 2020 and an estimate of the participation rate in this study is therefore 3981/4641 (85.8\%). Blood samples were collected from May 11 to June 11, 2020. Self-reported information regarding current workplace, active work with infected patients (suspected or confirmed COVID-19 cases), and self-suspicion of prior SARS-CoV-2 infection were collected at the time of sampling.

Serum samples were prepared from whole blood, inactivated at $56^{\circ} \mathrm{C}$ for 30 minutes and stored at $-20^{\circ} \mathrm{C}$ until analysis. IgG reactivity was measured towards three virus protein variants; Spike trimers comprising the prefusion-stabilized spike glycoprotein ectodomain, ${ }^{7}$ Spike S1 domain, and Nucleocapsid protein using multiplex bead array. Evaluation of the serology assay demonstrated a $99.2 \%$ sensitivity and $99.8 \%$ specificity. $^{3}$

Results are presented as prevalence and odds ratio (OR) with $95 \%$ confidence intervals (CI). Age, sex, date of test, active work with COVID-19 patients, and department were included in the multivariable logistic regression model. Statistical analyses were performed in $\mathrm{R} .{ }^{8}$ The study was approved by the Stockholm Ethical Review Board (dnr 2020-0162 and 202002724). All participants provided written informed consent and serology testing results were conveyed to participants.

\section{$\underline{\text { Results }}$}

In total, 3981 HCWs participated in the study. Participants had a mean age of 45.4 (11.9) years, $80.6 \%$ were female, and $64.3 \%$ responded that they had worked with patients with confirmed or suspected COVID-19.

Among the participating HCWs, 704 (17.7\%) were seropositive for IgG antibodies against SARS-CoV-2. The prevalence increased during the test period (Figure 1) and was $19.5 \%$ among men and $17.3 \%$ among women $(\mathrm{p}=0.28)$. Among HCWs below the age of 40 years the prevalence was $20.0 \%$, compared to $16.4 \%$ in HCWs 40 years of age and above $(p=0.29)$. 
medRxiv preprint doi: https://doi.org/10.1101/2021.01.28.21250664; this version posted January $29,2021$. The copyright holder for this preprint (which was not certified by peer review) is the author/funder, who has granted medRxiv a license to display the preprint in All rights reserved. No reuse allowed without permission.

HCWs who reported that they had worked with COVID-19 patients had a higher prevalence of antibodies, $21.1 \%$ compared to $11.7 \%$ without exposure, ORadj 1.96 (95\% CI 1.59 - 2.42). Self-reported suspicion of COVID-19 symptoms prior to the study was associated with higher prevalence of a positive test, $46.4 \%$ compared to $5.5 \%$ among HCWs who had not suspected previous infection, $(\mathrm{p}<0.01)$. Among the seropositive HCWs, $10.5 \%$ had been asymptomatic (no suspicion of a previous SARS-CoV-2 infection).

Seroprevalence differed between departments: HCWs within the Departments of Cardiology, Infectious diseases, and Internal Medicine had a significantly higher prevalence compared to HCWs at the rest of the hospital after adjustment for sex, age, date of test, and active work with COVID-19 patients (Figure 2). In contrast, HCWs from the Departments of Anesthesiology/ ICU, Obstetrics/ Gynecology, and Pediatrics had a lower prevalence compared to the rest of the hospital.

\section{Discussion}

This study found a prevalence of $17.7 \%$ of IgG antibodies against SARS-CoV-2 among HCWs in a large cohort of HCWs from Stockholm, Sweden sampled during the later phases of the first wave of the epidemic. The seroprevalence was similar to the $19.1 \%$ reported among 2,149 HCWs at Danderyd Hospital, a hospital of equivalent size in the Stockholm area, ${ }^{3}$ whereas Karolinska University Hospital demonstrated a lower seroprevalence of $11.5 \%$ among 12,928 HCWs. ${ }^{9}$ Globally, seroprevalences among HCWs have ranged from $0 \%$ to $45.3 \%{ }^{6}$ Residents in Stockholm had a seroprevalence of around $10 \%$ during the time of our study. ${ }^{10}$ Our results indicate that HCWs caring for COVID-19 patients had an increased risk of infection with SARS-CoV-2 during the first wave of the pandemic, but that this risk varied greatly. 
medRxiv preprint doi: https://doi.org/10.1101/2021.01.28.21250664; this version posted January $29,2021$. The copyright holder for this preprint (which was not certified by peer review) is the author/funder, who has granted medRxiv a license to display the preprint in All rights reserved. No reuse allowed without permission.

Self-reported high suspicion of infection has previously been associated with seropositivity. ${ }^{11-}$

${ }^{13}$ In our study, $10.5 \%$ of the seropositive HCWs did not suspect a previous SARS-CoV-2 infection and were thus likely to have had an asymptomatic infection. The proportion of infected individuals that have asymptomatic infections is somewhat variable in the literature, with a recent systematic review estimating about $30 \% .^{14}$

As in previous studies, ${ }^{3-5}$ an increased prevalence was seen in HCWs who had been in contact with COVID-19 patients. Lower prevalence in the Pediatrics and Obstetrics/ Gynecology Departments was to be expected due to low exposure to patients infected with SARS-CoV-2 in these settings. HCWs from the Departments of Cardiology, Infectious diseases, and Internal Medicine were highly involved in the care of COVID-19 patients. The higher seroprevalence in these departments indicates an increased risk of infection for HCWs in these settings, which could not be explained by age, sex, patient contact or date of test. Interestingly, as in the study by Grant et al., ${ }^{4} \mathrm{HCW}$ at Anesthesiology/ ICU had a lower seroprevalence compared to the rest of the hospital. This could reflect the use of enhanced personal protective equipment or that the COVID-19 patients at the ICU may be in a later stage of the disease when viral loads of patients might have decreased.

During the spring, many HCWs were relocated within the hospital. Current workplace was self-reported, and a limitation of this study is that we were not able to fully distinguish primary (regular) workplace from workplace during the period of interest. Furthermore, we did not collect information regarding use of protective equipment or other potential exposures such as contact with infected persons outside work or with infected HCWs at work. The number of COVID-19 patients admitted to our hospital peaked in the weeks before this study. The fact that the seroprevalences increased with calendar time suggests that the first wave of the epidemic was still ongoing during the time of this study. However, PCR testing for the virus was not performed. 
medRxiv preprint doi: https://doi.org/10.1101/2021.01.28.21250664; this version posted January 29, 2021. The copyright holder for this preprint (which was not certified by peer review) is the author/funder, who has granted medRxiv a license to display the preprint in All rights reserved. No reuse allowed without permission.

\section{$\underline{\text { Conclusion }}$}

The prevalence of SARS-Cov-2 IgG antibodies was higher in HCWs caring for COVID-19 patients. However, the risk was highly variable between departments suggesting that other factors are important for the risk of the infection. 
medRxiv preprint doi: https://doi.org/10.1101/2021.01.28.21250664; this version posted January 29, 2021. The copyright holder for this preprint (which was not certified by peer review) is the author/funder, who has granted medRxiv a license to display the preprint in All rights reserved. No reuse allowed without permission.

\section{$\underline{\text { Acknowledgements }}$}

We would like to thank all HCWs at Södersjukhuset for participating in the study, and all the staff at Södersjukhuset and Karolinska University Hospital directly involved in the study. We are thankful to the SciLifeLab Autoimmunity and Serology profiling facility and all associated personnel for performing the serology analysis. We would also like to thank Jonas Blomqvist, Karolinska University Hospital, for study support.

\section{$\underline{\text { Conflict of interest statement }}$}

No conflicts of interest are reported.

\section{Funding}

The study was supported by the County Council of Stockholm (Region Stockholm). SK was supported by Region Stockholm (clinical postdoctoral appointment). EM was supported by research grants from the Swedish Research Council, The Swedish Heart-Lung Foundation and Region Stockholm (ALF). SH was supported by Region Stockholm, Knut and Alice Wallenberg foundation and Erling-Persson family foundation. 
medRxiv preprint doi: https://doi.org/10.1101/2021.01.28.21250664; this version posted January $29,2021$. The copyright holder for this preprint (which was not certified by peer review) is the author/funder, who has granted medRxiv a license to display the preprint in All rights reserved. No reuse allowed without permission.

\section{$\underline{\text { References }}$}

1. Region Stockholm. Bekräftat fall av nya coronaviruset i Stockholm - patient vårdas isolerat på infektionsklinik. Hälsa och vård - Nyheter, https://www.sll.se/verksamhet/halsa-och-vard/nyheter-halsa-och-vard/2020/02/corona/ (2020, accessed 30 November 2020).

2. Region Stockholm. Lägesrapport om arbetet med det nya coronaviruset. Hälsa och vård - Nyheter, https://www.sll.se/verksamhet/halsa-och-vard/nyhetslista-halsa-och-vard (2020, accessed 30 November 2020).

3. Rudberg A-S, Havervall S, Månberg A, et al. SARS-CoV-2 exposure, symptoms and seroprevalence in healthcare workers in Sweden. Nat Commun 2020; 11: 5064.

4. Grant JJ, Wilmore SMS, McCann NS, et al. Seroprevalence of SARS-CoV-2 antibodies in healthcare workers at a London NHS Trust. Infect Control Hosp Epidemiol 2020; 1-3.

5. Iversen K, Bundgaard H, Hasselbalch RB, et al. Risk of COVID-19 in health-care workers in Denmark: an observational cohort study. Lancet Infect Dis. Epub ahead of print 3 August 2020. DOI: 10.1016/S1473-3099(20)30589-2.

6. Galanis P, Vraka I, Fragkou D, et al. Seroprevalence of SARS-CoV-2 antibodies and associated factors in health care workers: a systematic review and meta-analysis. J Hosp Infect. Epub ahead of print 16 November 2020. DOI: 10.1016/j.jhin.2020.11.008.

7. Wrapp D, Wang N, Corbett KS, et al. Cryo-EM structure of the 2019-nCoV spike in the prefusion conformation. Science 2020; 367: 1260-1263.

8. R Development Core Team 2019. R: A Language and Environment for Statistical Computing. Vienna, Austria: R Foundation for Statistical Computing.

9. Dillner J, Elfström M, Blomqvist J, et al. Antibodies to SARS-CoV-2 and risk of future sickness. medRxiv 2020; 2020.09.14.20194308.

10. Public Health Agency of Sweden. Påvisning av antikroppar efter genomgången covid19 i blodprov från öppenvården (Delrapport 1). Public Health Agency of Sweden, https://www.folkhalsomyndigheten.se/contentassets/9c5893f84bd049e691562b9eeb0ca2 80/pavisning-antikroppar-genomgangen-covid-19-blodprov-oppenvarden-delrapport1.pdf (3 September 2020).

11. Moscola J, Sembajwe G, Jarrett M, et al. Prevalence of SARS-CoV-2 Antibodies in Health Care Personnel in the New York City Area. JAMA 2020; 324: 893-895.

12. Self WH, Tenforde MW, Stubblefield WB, et al. Seroprevalence of SARS-CoV-2 Among Frontline Health Care Personnel in a Multistate Hospital Network - 13 Academic Medical Centers, April-June 2020. MMWR Morb Mortal Wkly Rep 2020; 69: $1221-1226$.

13. Stubblefield WB, Talbot HK, Feldstein L, et al. Seroprevalence of SARS-CoV-2 Among Frontline Healthcare Personnel During the First Month of Caring for COVID-19 Patients - Nashville, Tennessee. Clin Infect Dis Off Publ Infect Dis Soc Am. Epub ahead of print 6 July 2020. DOI: 10.1093/cid/ciaa936. 
medRxiv preprint doi: https://doi.org/10.1101/2021.01.28.21250664; this version posted January 29, 2021. The copyright holder for this preprint (which was not certified by peer review) is the author/funder, who has granted medRxiv a license to display the preprint in All rights reserved. No reuse allowed without permission.

14. Johansson MA, Quandelacy TM, Kada S, et al. SARS-CoV-2 Transmission From People Without COVID-19 Symptoms. Infect Dis; 8. 
medRxiv preprint doi: https://doi.org/10.1101/2021.01.28.21250664; this version posted January $29,2021$. The copyright holder for this preprint (which was not certified by peer review) is the author/funder, who has granted medRxiv a license to display the preprint in All rights reserved. No reuse allowed without permission.

$\underline{\text { Tables }}$

Table 1: Adjusted ORs for a positive SARS-CoV-2 IgG test in multivariable analyses

Variables

OR $\quad 95 \%$ CI

$\mathbf{P}$

\begin{tabular}{|c|c|c|c|c|}
\hline Age, Higher or equal than 40 years $^{1}, n=2,506$ & 1.10 & 0.92 & -1.30 & 0.29 \\
\hline Sex Male $^{2}, n=771$ & 1.12 & 0.91 & -1.37 & 0.28 \\
\hline Test date, second week ${ }^{3}, n=877$ & 1.16 & 0.93 & -1.44 & 0.19 \\
\hline Test date, third to fifth week ${ }^{3}, \mathrm{n}=1,366$ & 1.49 & 1.24 & -1.80 & $<0.01$ \\
\hline $\begin{array}{l}\text { Active work with COVID-19 patients } \\
\text { Yes }^{4} n=2,560\end{array}$ & 1.96 & 1.59 & -2.42 & $<0.01$ \\
\hline $\begin{array}{l}\text { Active work with COVID-19 patients } \\
\text { Do not know }{ }^{4} n=283\end{array}$ & 1.03 & 0.69 & -1.55 & 0.88 \\
\hline
\end{tabular}

${ }^{1}$ Reference group: Age $<40$ years, $n=1,475$

${ }^{2}$ Reference group: Female, $n=3,210$

${ }^{3}$ Reference group: Test date, first week, $n=1,738$

${ }^{4}$ Reference group: Active work with COVID-19 patients, no $n=1,122$

OR Odds Ratio; CI Confidence Interval; P p-value 
medRxiv preprint doi: https://doi.org/10.1101/2021.01.28.21250664; this version posted January 29, 2021. The copyright holder for this preprint (which was not certified by peer review) is the author/funder, who has granted medRxiv a license to display the preprint in All rights reserved. No reuse allowed without permission.

\section{$\underline{\text { Figure captions }}$}

Figure 1: Prevalence of SARS-CoV-2 IgG antibodies by test date.

Divided into First week, n=1,738; Second week, n=877; Later weeks (week $3-5$ ), n=1,366

Error bars shows $95 \%$ confidence intervals.

\section{Figure 2: Differences between departments.}

The seroprevalence within the department is presented in parentheses, and the figure demonstrates Odds ratio (OR) and $95 \%$ confidence intervals (CI) from multivariable regression models comparing the department with all other departments adjusted for sex, age, date of test, and active work with COVID-19 patients. 


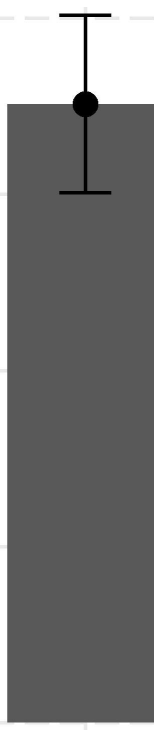

First week

Second week

Later weeks

Test date 


\section{Departments Seroprevalence, $\mathrm{n}(\%) \quad \mathrm{OR} \quad 95 \% \mathrm{Cl}$}

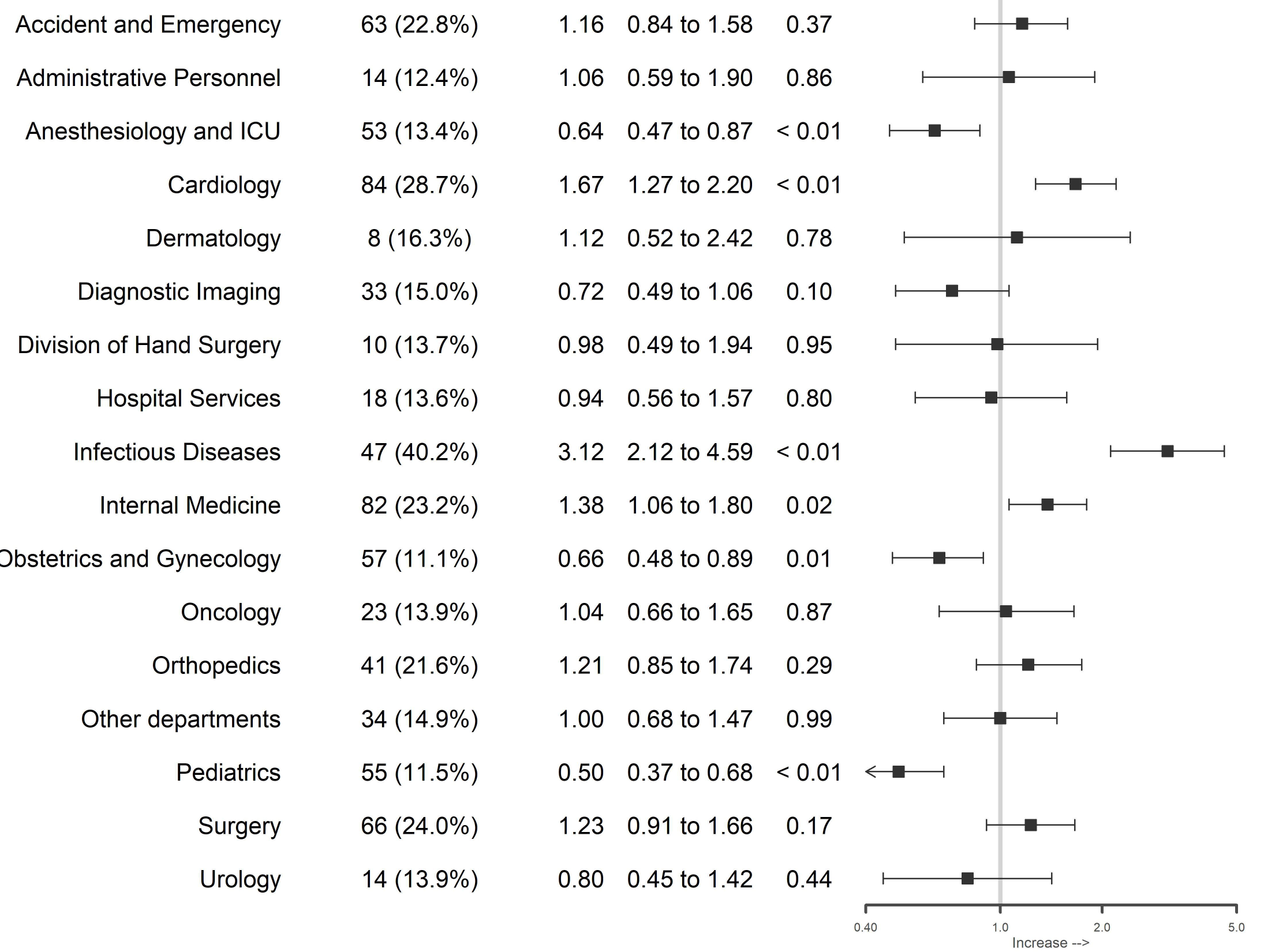

